\title{
Socio-environmental problems of single- industry towns and some ways of their solution
}

\author{
Aleksandr Maslennikov ${ }^{1, *}$, Aleksander Egorov ${ }^{1}$, Ilya Zubkov $^{2}$ \\ ${ }^{1}$ Nizhny Novgorod State Technical University named after R.E. Alekseev, 603950, 24 Minin str., \\ Nizhny Novgorod, Russia \\ ${ }^{2}$ Dzerzhinsk Polytechnic Institute, Nizhny Novgorod State Technical University named after R.E. \\ Alekseev, 606026, 49 Gaidar str., Dzerzhinsk, Russia
}

\begin{abstract}
Mono-profile municipalities (single-industry towns) are an important economic and social component of the Russian society. There are 319 single-industry towns, or $28 \%$ of the cities of the Russian Federation, on the territory of which, as a rule, just one main city-forming enterprise is located. The situation of single-industry towns is more vulnerable than other municipalities because of their decisive dependence on the sustainable position of the city-forming organizations. The directions formulated by regional and federal government bodies to improve economic stability and social welfare of single-industry towns are demonstrated on the example of a number of such settlements in the Nizhny Novgorod region. The environmental aspect belongs to the most important components of the territories well-being. It is shown in the article that solid-state gas-analyzing sensors can be the basis for constructing environmental monitoring systems. Their main types and properties are presented in this paper.
\end{abstract}

Currently, the state - both at the federal level and at the level of the constituent entities of the Russian Federation - pays special attention to the socio-economic development of mono-profile municipal entities (single-industry towns). In accordance with the Resolution of the Government of the Russian Federation No. 709 of July 29, 2014, a municipal entity is recognized as a single-industry (mono-profile) town if it simultaneously meets such criteria as: has the status of a city district or urban settlement, with the exception of the municipal formations in which the legislative (representative) authority of the constituent entity of the Russian Federation operates; the resident population of the municipality exceeds 3 thousand people; the number of employees of one of the organizations (one of the branches of a legal entity in the municipality or several organizations) that carry out the same type of basic economic activity on the territory of the municipality or whose activities carried out within the framework of a single production and technological process reached in the five-year period preceding the date of approval of the list of mono-profile municipal entities of the Russian Federation is $20 \%$ of the average number of employees of all organizations, working on the territory of the municipality; implementation by one of these

* Corresponding author: mavdoc@rambler.ru 
organizations (one of the branches of a legal entity in the municipality or several organizations) of activities on the extraction of minerals (other than oil and gas), and (or) production, and (or) processing of industrial products [1]. According to official figures, about $28 \%$ of Russian cities (319 single-industry towns) belong to the mono-profile municipalities [2].

The situation of single-industry towns is more vulnerable than other municipalities because of their decisive dependence on the sustainable position of city-forming enterprises and organizations, which are legal entities whose number of employees is at least $25 \%$ of the working population of the locality, or other organizations with more than 5 thousand people [3]. Depending on the socio-economic situation, the current single-industry towns is divided into three categories. The first is mono-profile municipal formations with the most difficult social and economic situation. The second one is single-industry towns, in which there are risks of worsening of the socio-economic situation. And the third category includes mono-profile towns with a stable social and economic situation.

Taking into consideration difficult situation of single-industry towns, the state seeks to create and implement comprehensive programs for their development. The purpose of these programs is to reduce the dependence of single-industry towns on the activities of cityforming organizations (enterprises) by creating new jobs not related to their activities, and improving the quality of the urban environment in mono-profile municipalities. The key indicators that testify the achievement of the programs' goals are traditionally the following: the number of new jobs created not related to the activities of the town-forming enterprise, the level of registered unemployment, and the volume of attracted investments in fixed assets. This is evidenced, in particular, by the briefing materials of the program "Integrated development of mono-profile towns in the Nizhny Novgorod region" for 20182020 [1]. At present, there are 12 single-industry towns in the Nizhny Novgorod region. Data for some towns and for the region as a whole are presented in the Table 1.

Achieving these goals will require a significant increase in anthropogenic pressure on the environmental complexes of single-industry towns, which are already overloaded. Meanwhile, in the programs for the development of single-industry towns not so much attention is paid to the environmental problems. For example, the program for the integrated development of the mono-profile town of Zavolzhye of the Gorodetskiy municipal district of the Nizhny Novgorod region contains only one project related to the environmental sphere in terms of creating a comfortable urban environment. It deals with the creation of a park zone, for arrangement of which it is planned to spend 11.75 million rubles [5]. At the same time, there are 9 projects in the section «Assistance in the implementation of investment projects», the environmental «cleanliness» of which raises considerable doubts. The names of the projects speak about this, for example: «Design and development of the production of new gasoline engines ZMZ (Zavolzhskiy motor plant A.E.) for the enterprises of the Russian automotive industry», "Organization of the production of packaging and glass products for the pharmaceutical industry «SHOTT Pharmaceutical Packaging Ltd.»», «Modernization of equipment of «Zavolzhskiy Caterpillar Tractor Plant», and «Development of production of auto components «LEONI Rus, Ltd.»».

Meanwhile, the solution of tasks that are not related to the functioning of city-forming enterprises does not cancel, but rather complements the environmental aspect of their activities, since in the short and medium term perspective, the city-forming enterprises will remain the key link in the mono-profile towns' economy. Any activity, including technical re-equipment, should be considered by the management of these enterprises in the context of solving multi-level environmental issues. As the Russian researchers A.E. Vossina and M.A. Kustikova correctly underline, corporate individual and team-building HR projects and programs aimed at forming the environmental consciousness of the company's 
personnel, especially those related to the environmental aspects of their activities, should become measures to implement the environmental policies of the city-forming enterprises [6].

Table 1. Plan to achieve the indicators of the program "Integrated development of single-industry towns of the Nizhny Novgorod region" for 2018-2020.

\begin{tabular}{|c|c|c|c|c|c|}
\hline \multirow{2}{*}{ Indicator } & \multirow{2}{*}{$\begin{array}{l}\text { Indicator } \\
\text { Type }\end{array}$} & \multirow{2}{*}{$\begin{array}{l}\text { Baseline } \\
\text { value } \\
(2015)\end{array}$} & \multicolumn{3}{|c|}{ Period, year } \\
\hline & & & 2018 & 2019 & 2020 \\
\hline $\begin{array}{l}\text { 1. The number of new jobs created, not } \\
\text { related to the functioning of the town- } \\
\text { forming enterprise; units, total, including } \\
\text { for some single-industry towns }\end{array}$ & Main & 1052 & 6327 & 7426 & 8444 \\
\hline Balakhna & & 429 & 1099 & 1199 & 1299 \\
\hline Vyksa & & 136 & 1852 & 2280 & 2705 \\
\hline Zavolzhye & & 39 & 833 & 972 & 1105 \\
\hline Kniaginino & & 23 & 170 & 180 & 200 \\
\hline Pavlovo & & 152 & 534 & 626 & 718 \\
\hline $\begin{array}{|lccc|}2 . & \text { The level of } & \text { registered } \\
\text { unemployment, } \%\end{array}$ & Main & & & & \\
\hline Balakhna & & 0.88 & 0.63 & 0.63 & 0.63 \\
\hline Vyksa & & 0.93 & 0.53 & 0.46 & 0.41 \\
\hline Zavolzhye & & 1.18 & 0.55 & 0.54 & 0.53 \\
\hline Kniaginino & & 0.9 & 0.91 & 0.9 & 0.89 \\
\hline Pavlovo & & 0.44 & 0.27 & 0.27 & 0.27 \\
\hline $\begin{array}{l}\text { 3. The volume of attracted investments in } \\
\text { fixed assets, million rubles; total, } \\
\text { including for some single-industry towns: }\end{array}$ & Main & 6161.1 & 40696.2 & 54513.9 & 64225.3 \\
\hline Balakhna & & 688.7 & 2641.9 & 3126.5 & 3620.8 \\
\hline Vyksa & & 1416.0 & 24841.0 & 34627.0 & 40805.0 \\
\hline Zavolzhye & & 817.5 & 2906.7 & 3772.7 & 4493.6 \\
\hline Kniaginino & & 55.3 & 167.0 & 177.0 & 189.5 \\
\hline Pavlovo & & 1125.2 & 3565.1 & 4998.1 & 6518.5 \\
\hline
\end{tabular}

In this regard, the most important is the system approach, through which it is possible to address all levels of functioning of the city-forming enterprises: from the micro-level, where pollution occurs, to the macro-level, where economic and environmental resources are allocated [7].

When formulating the goals of their environmental policy, a growing number of enterprises realize that the stability of their development depends on how positively their image is formed in the eyes of the public and the state. Increasingly, enterprise managers come to the conclusion that a balanced combination of environmental, economic and socially-oriented principles in their production activities is the basis for their competitiveness. At the same time, the priority is the creation and implementation of technologies that take into account the environmental development, in addition to economics.

The example of Vyksa Steel Works, which, along with four other large enterprises, is a part of the United Metallurgical Company (Moscow) is indicative in this respect. The latter gives paramount attention to minimization of the impact of its activities on the environment, and the development of responsible use of resources [8]. The Company puts into motion «The standards of management and performance in the field of environmental 
protection, health and industrial safety», based on the principles of leadership and responsibility, integration and advanced management system, environmental, health and industrial safety assessment, public discussion and informing the population, monitoring, control and evaluation of results [9].

In recent years, the conduct of environmental expertise, as well as the issuance of assessments in the field of health protection and industrial safety of new activities, both at the strategic planning stage and at all stages of operational planning, including selection of planning and design decisions, and in current activities of the company's enterprises has become the most important procedure. This ensures the following: identification of environmental aspects and production hazards and their ranking; effective management of significant environmental aspects of activities aimed at reducing the impact on health of personnel and the public, the environment and production facilities; systematic independent evaluation of the management system through internal and external audits. These measures make it possible to improve the ecological situation of the territories adjacent to the cityforming enterprises of single-industry towns that have their own environmental problems, the main features of which in the field of air quality are:

- Small number and similarity of the characteristics of pollutants characteristic for the city-forming enterprise due to its specific production orientation;

- Low share of the main priority pollutants of atmospheric air due to low population density and motor transport, as well as a high proportion of green spaces on the territory, as compared to large cities;

- Geographic localization of the city-forming enterprise, and the source of pollution together with it, in one district of the city.

Obviously, the first step towards improving the environmental situation is the knowledge of this situation. Various methods of gas analysis can be used to assess air pollution: chemical and analytical, instrumental, and sensory.

Chemical and analytical methods are worked out, they are sensitive enough, but cumbersome, non-expressive and require a lot of manual labor. Instrumental methods, with high universality and sufficient sensitivity, are also often non-expressive, very expensive in terms of the equipment used and also require manual controls. Sensory methods have a relatively cheap material and technical base, sufficient sensitivity and speed, and can work in automated and automatic modes.

Solid-state gas-analyzing sensors (SGS) are the basic elements for realization of sensory methods, which can be divided into several groups that differ in the principles of work of the sensing element and in the output signals. Usually SGS are divided into electrochemical, thermo-catalytic, semiconductor, piezoelectric mass-sensitive, and optical [10]. For determining the pollutants of the mono-profile towns, the last two groups of SGS piezoelectric mass-sensitive and optical ones - are of the greatest interest. This is due to their common feature meaning that the parameters of sensitivity and speed to the analyzed pollutant, as well as the pollutant itself, are determined by a special coating, in the form of a film, applied to the surface of the sensor. Therefore, in order to obtain a sensitive element, it is necessary to select the desired sensitive coating of SGS to the pollutant of interest. Taking into account a small number of pollutants in mono-profile towns, monitoring systems can contain only a few highly selective sensors for these harmful gases, without the need for complex processing of their signals, which simplifies and reduces the cost of the air monitoring system.

Let us briefly characterize the aforementioned sensors.

Piezoelectric sensors are divided into two main subgroups: sensors based on volumetric acoustic waves (VAW-sensors), and sensors based on surface acoustic waves (SAWsensors). [11] Their main difference from each other is the factors that cause a change in the output signal of the sensor under the impact of the analyzed gas medium. 
Sensors based on volumetric acoustic waves are susceptible, first of all, to the attached mass, located on the sensor electrodes. Therefore, another their well-established name is piezoquartz microbalances [11]. Sometimes electrodes themselves can perceive gas components, for example, hydrogen when performing electrodes from palladium or the vapor of mercury with gold electrodes. But more often electrodes are covered with a special coating (mediating agent), somehow interacting with the gaseous component of the environment. This interaction can be caused by physical sorption, or by a chemical reaction that must necessarily be reversible when solving the tasks of automatic gas analysis. If a reversible reaction proceeds, a device will be obtained, the output signal of which will be determined by the current concentration of the gas component. In this case, the sensitivity and speed of such a sensor will be defined by the equilibrium constant and the rates of direct and reverse reactions, respectively [12]. On the basis of VAW-sensors, a large number of different devices for controlling the gaseous medium have been created. For example, selective heptyl vapor sensor is described in [13]. This sensor can be used both in the "field" conditions, in assessing the state of the terrain after missiles launching or in the places where the missiles have fallen down, and in the places where heptyl is produced and stored. The advantages of VAW-sensors include a high sensitivity to the connected mass at a relatively low operating frequency, which is usually a few tens of $\mathrm{MHz}$, as well as the availability of the original piezoquartz resonators.

The closest «relatives» of VAW-sensors are SAW-sensors. They have a much more complex surface design and are implemented based on modern photolithographic technologies used in microelectronics. On the surface of the SAW-element, depending on its primary (radio engineering) purpose (resonator, filter, and delay line), a corresponding combination of metal electrodes is formed. In particular, for the construction of the delay lines, two groups of interdigital transducers are created on the surface, which carry out radiation and receive an acoustic wave propagating along the surface of the piezoceramic plate. There is a gap free from the electrodes, between which the surface wave disseminates. At this interval, a gas-sensitive coating is applied, which changes the characteristics of the wave impacting the surface of this part of the sensor. This, in turn, leads to a change in the frequency of the output signal of the sensor.

The sensitivity mechanism of SAW-sensors is much more complicated, since besides the attached mass, the sensor feels the change in other properties of the applied coating, such as elasticity, hardness, and dielectric properties. The operating frequency of SAW devices can vary in the range from tens to hundreds of MHz. Due to the higher frequency, the sensors have a greater sensitivity to the attached mass than the VAW-sensors. The physics of the SAW element is described in detail in [14]. The sensitivity threshold of piezoelectric sensors to the attached mass is about $10^{-12} \mathrm{~g}$.

Optical sensors (OS) are characterized by the explosion and fire safety in operation, insensitivity to radio frequency interference, the possibility of connecting sensors to the measuring device with the help of fiber-optic lines, and low power consumption. Sensors can be divided into two subgroups - active and passive types. In active OS, regardless of their design, there is a sensitive coating containing molecules of analytical reagents. They, entering into a specific interaction with the molecules of the gas controlled by the sensor, change not only mass, elasticity, hardness, as in the case of piezoelectric sensors, but also their optical properties. Optical sensors of the active type must be reversible [15]. According to the principle of their work, active OS are divided into photometric, reflective and fluorometric ones.

Sensors, in which there is no such coating, are of a passive type. The advantage of passive sensors is the absence of a phase of adsorption and desorption of gas by a sensitive layer that improves the speed of the sensor. However, this also determines their low selectivity and sensitivity. 
An important technical property of the OS is its lower sensitivity to humidity in comparison with VAW- and SAW-sensors, because the signal in the OS does not arise due to the addition of the mass, but because of the presence of a color reaction that, when the humidity is changed, is insignificant or absent at all.

Thus, taking into account the basic properties of SGS, the following conclusions can be drawn on the social and environmental state of single-industry towns:

1. Mono-profile towns having one or two city-forming enterprises are very important social and economic elements of the state.

2. Despite the attempts of the authorities of different levels to diversify the production structure of single-industry towns, it is obvious that for a long time their life will depend significantly on the city-forming enterprises.

3. This dependence is important in terms of environment. These are the city-forming enterprises that are the main source of atmospheric air pollution on the territories of singleindustry towns.

4. Due to the specifics of atmospheric pollution in such settlements, the most promising for monitoring the state of the atmosphere are systems built on the basis of solid-state gas analytical sensors, primarily piezo-resonance and of active optical types.

5. The use of such sensors will make it possible to obtain an environmental monitoring system that is relatively inexpensive and sufficiently effective, under the conditions of the application in question.

The work was supported by the Ministry of Education and Science of the Russian Federation. The agreement No. is 14.577.21.0144 of November 28, 14. The unique project ID is RFMEFI57714X0144.

\section{References}

1. Government of the Russian Federation, Resolution No. 709 of July 29, 2014 on the criteria for classifying municipal entities of the Russian Federation as mono-profile (single-industry towns) and categories of single-profile municipal entities of the Russian Federation (single-industry towns) depending on the risks of deterioration of their socioeconomic status (http://www.garant.ru/products/ipo/prime/doc/70607142/\#ixzz5 E9WaedVu, Moscow, 2014)

2. Government of the Russian Federation, Order of the Government of the Russian Federation of July 29, 2014 No. 1398-r on the list of mono-profile municipal entities of the Russian Federation (single-industry towns) (as amended on May 13, 2016) (http://docs.cntd.ru/document/420210942, Moscow, 2016)

3. Federal Law No. 127-FZ of October 26, 2002 (as amended on March 7, 2013) on insolvency

(http://www.consultant.ru/document/cons_doc_LAW_39331/f1bf

(bankruptcy) 319e5d3b6493a9776f524f3d8841fd29acaa, Moscow, Russia, 2016)

4. Government of the Nizhny Novgorod region, Order of 26 January 2018 No. 66-r on the approval of the passport of the program Integrated development of single-industry towns of the Nizhny Novgorod region for 2018-2020 (http://docs.cntd.ru/document/465580323, Nizhniy Novgorod, 2018)

5. The Program passport "Integrated development of the monotown of the Zavolzhye of Gorodetsky municipal district of the Nizhny Novgorod region" (http://zavnnov.ru/media/monogorod/pasport.pdf, Nizhniy Novgorod, 2018) 
6. A. E. Vossina, M. A. Kustikova, Scientific journal of NIU ITMO - Series on Economics and Environmental Management, 1 (2015)

7. E. L Ochirova, Economic and ecological aspects of sustainable development of modern economy (Irkutsk State Transport University, Irkutsk, 2009)

8. The official website of the United Metallurgical Company, section "Values. Security and the Environment" (https://omk.ru/values/environment, Moscow, 2018)

9. Standards of management and performance in the field of environmental protection, health and industrial safety of United Metallurgical Company (https://omk.ru/values/Стандарты\%20менеджмента\%20и\%20результативности\%2 0в\%20области\%20охраны\%20окружающей\%20среды,\%20здоровья $\% 20$ н $\% 20$ про мышленной\%20безопасности.pdf, Moscow, 2018)

10. R. In Cattrall, Chemical sensors (Scientific World, Moscow, 2000)

11. V. V. Malov, Piezoresonance sensors (Energoatomizdat, Moscow, 1989)

12. H. A. Burlaenko, A. B. Maslennikov, SG Sazhin, Defectoscopiya, 4 (1996)

13. A. A. Grechnikov, A. N. Mogilevsky, Nano- and Microsystem Technology, 2 (2001)

14. T. Kertzman, Piezoelectric Proc. AFCS 25, 103 (1971).

15. R. Narayanaswamy Anal. Proc., 22, 7 (1985) 